\title{
Analisis Faktor-faktor yang Mempengaruhi Keputusan Ekonomi Rumahtangga Petani Padi Sawah di Kecamatan Bangkinang Kabupaten Kampar
}

\author{
Sri Rumondang Oktavia Panjaitan*, Djaimi Bakce, dan Deby Kurnia \\ Fakultas Pertanian, Universitas Riau
}

\begin{abstract}
Abstrak: Secara umum penelitian ini bertujuan untuk menganalisis faktor-faktor yang berpengaruh terhadap keputusan ekonomi rumahtangga petani padi sawah terkait dengan produksi, alokasi waktu kerja, pendapatan, dan pengeluaran. Pendekatan ekonometrika model persamaan simultan dengan metode Two-Stage Least Square (2SLS) digunakan untuk menjawab tujuan penelitian. Faktor- faktor yang mempengaruhi produksi, alokasi waktu kerja, pendapatan, dan pengeluaran yaitu upah, harga input, harga output, umur, pendidikan, pengalaman kerja, angkatan kerja keluarga, jumlah anggota keluarga, dan jumlah anak sekolah. Data yang digunakan adalah data cross section tahun 2016 yang diperoleh dari wawancara langsung dengan 45 petani padi sawah di Kecamatan Bangkinang. Temuan utama dari penelitian ini menunjukkan Peubah total tenaga kerja dalam usaha responsif mempengaruhi produksi. Alokasi waktu kerja dipengaruhi secara responsif oleh pendapatan dalam usahatani padi sawah. Sementara itu, tidak ada peubah yang responsif mempengaruhi pendapatan luar usahatani padi sawah. Pengeluaran rumahatangga dipengaruhi secara responsif oleh pendapatan total rumahtangga, tabungan, total curahan kerja rumahtangga, dan konsumsi total rumahtangga.
\end{abstract}

Kata kunci: ekonomi rumah tangga; keputusan; model; padi sawah

\begin{abstract}
This research aims to analyse factors affecting the economic household decision of paddy farmers, associated with production, allocation of working time, income and expenditure. An econometric model of simultaneous equations approach to the Two-Stage Least Square method (2SLS) was used to answer the research objectives. The factors that influence the production, allocation of work time, income, and expenses are wages, input prices, output prices, age, education, work experience, family labour force, the number of family members, and the number of school children. The data used was the 2016 crosssection data obtained by interviewed 45 paddy farmers in Bangkinang Sub-district. The main findings of this research showed variable of the used labour was responsive respect to production. Allocation of working time was responsive respected by the income of paddy farming. In the other hand, there was no variable that responsive respect to income for nonpaddy agriculture. Expenditures of the household were responsively respected by total income, saving, the total of working time allocation and total consumption.
\end{abstract}

Keywords: economic household; decision; model; paddy

JEL Classification: D1O; D91

* Penulis koresponden

E-mail: srirumondangoktaviapanjaitan@gmail.com 


\section{PENDAHULUAN}

Peran padi, selain sebagai sumber pangan pokok juga menjadi sumber penghasilan bagi petani dan kebutuhan hidup sehari-hari bagi jutaan penduduk. Padi telah menjadi komoditas strategis dalam kehidupan bernegara di Indonesia. Kabupaten Kampar merupakan salah satu daerah penghasil padi di Provinsi Riau.

Salah satu kecamatan penyumbang produksi terbesar di kabupaten Kampar adalah Bangkinang. Kecamatan Bangkinang merupakan kecamatan dengan tingkat produksi padi sawah tertinggi dibandingkan kecamatan lainnya. Produksi padi sawah di kecamatan Bangkinang mencapai 4.810,00 ton dengan luas lahan $740 \mathrm{Ha}$. Walaupun memiliki produksi terbesar, tahun 2014 terjadi penurunan luas panen padi sawah dan produksi dari tahun sebelumnya.

Penurunan produksi yang sejalan dengan penurunan luas lahan mengindikasikan bahwa adanya kendala terkait luas lahan yang masih terbatas bahkan cenderung menurun. Penurunan produksi berdampak terhadap penurunan pendapatan petani sehingga kegiatan usahatani tidak mampu untuk mencukupi kebutuhan rumahtangga, oleh karena itu menyebabkan anggota rumahtangga petani padi sawah mengalokasikan waktunya untuk bekerja di luar usahatani untuk mendapatkan tambahan pendapatan.

Terdapat beberapa faktor yang mempengaruhi keputusan ekonomi rumahtangga terkait kegiatan produksi, alokasi waktu kerja, pendapatan, dan pengeluaran rumahtangga yaitu faktor internal dan eksternal. Menurut Hernanto (1996) yang termasuk ke dalam faktor internal adalah petani pengelola, tanah usahatani, tenaga kerja, modal, tingkat teknologi, kemampuan petani mengalokasikan penerimaan keluarga dan jumlah keluarga. Sementara itu, yang termasuk faktor eksternal adalah tersedianya sarana transportasi dan komunikasi, aspek-aspek yang menyangkut pemasaran hasil dan bahan usahatani (harga hasil, harga sarana produksi dan lain-lain) dan sarana penyuluh bagi petani.

Berbagai faktor yang mempengaruhi proses produksi akan mempengaruhi alokasi waktu kerja, selanjutnya akan mempengaruhi perolehan pendapatan dan akhirnya akan mempengaruhi jumlah dan pola pengeluaran rumahtangga. Dari telaahan diatas penelitian ini dilakukan dengan tujuan untuk mengetahui faktor-faktor internal dan eksternal yang mempengaruhi keputusan ekonomi rumahtangga dari produksi, alokasi waktu kerja, pendapatan, dan pengeluaran rumahtangga petani padi sawah.

\section{KAJIAN PUSTAKA}

Teori Neoklasikal ekonomi merupakan awal dari terbentuknya model dasar ekonomi rumahtangga dengan unit analisis yang mendasari teori ini adalah analisis mikro ekonomi pada tingkat konsumen dan perusahaan. Singh et al. (1986) menggagas model rumahtangga yang dapat digunakan untuk menganalisis rumahtangga petani dan rumahtangga selain pertanian. Asumsi yang digunakan dalam model ini adalah bahwa rumahtangga selalu bekerja dengan memaksimalkan utilitas, dimana utilitas diperoleh dari konsumsi dari barang yang dihasilkan rumahtangga, barang yang dibeli di pasar dan waktu rekreasi yang dikonsumsi (leisure). Grossbard (2010) mendefenisikan rumahtangga sebagai kesatuan dari individu tunggal, dimana kebanyakan model rumahtangga bersifat individual. Individu di dalam rumahtangga mempunyai fungsi utilitas dan dibatasi kendala sumberdaya personal. 
Dalam melakukan aktivitas ekonomi, setiap rumahtangga tidak hanya melakukan aktivitas konsumsi dan produksi secara parsial, namun melakukan kedua aktivitas tersebut secara simultan. Dalam kenyataannya, cakupan rumahtangga sebagai satu kesatuan, tidak ada rumahtangga yang melakukan aktivitas secara parsial, dengan kata lain aktivitas produksi dan konsumsi dilakukan secara simultan.

Penelitian tentang ekonomi rumahtangga yang dilakukan secara simultan pada umumnya menggunakan model ekonomi rumahtangga yang dirumuskan oleh Becker (1965). Becker (1965) merumuskan agricultural household model (model ekonomi rumahtangga pertanian) yang mengintegrasikan aktivitas produksi dan konsumsi sebagai satu kesatuan dan penggunaan tenaga kerja dalam keluarga. Terdapat sejumlah asumsi yang digunakan dalam model ekonomi rumahtangga ini, yaitu: (1) kepuasan rumahtangga dalam mengonsumsi tidak hanya ditentukan oleh barang dan jasa yang diperoleh di pasar, tetapi juga ditentukan oleh berbagai komoditas yang dihasilkan dalam rumahtangga, (2) unsur kepuasan tidak hanya barang dan jasa, tetapi termasuk waktu, (3) waktu dan barang atau jasa dapat digunakan sebagai faktor produksi dalam aktivitas produksi rumahtangga, dan (4) rumahtangga bertindak sebagai produsen sekaligus konsumen. Sesuai dengan teori perilaku rumahtangga yang dikembangkan oleh Becker (1976), bahwa utilitas tidak tergantung pada jumlah barang dan jasa yang dibeli, melainkan oleh jumlah komoditas rumahtangga yang mereka hasilkan meliputi: kualitas dan kuantitas anak, martabat, rekreasi, persahabatan, kasih sayang, status kesehatan dan status perkawinan, kemudian anggapan ini menjadi dasar model ekonomi rumahtangga Becker.

Dalam menganalisis ekonomi perlu diperhatikan dua hal, yaitu: Pertama, perlu ditekankan bahwa harga barang dan jasa yang dikonsumsi rumahtangga dianggap sesuai dengan harga pasar. Kedua, perlu dipastikan bahwa perilaku rumahtangga dalam aktivitas produksi dan konsumsi bersifat separable (terpisah) atau nonseparable (simultan). Apabila persamaan produksi, curahan tenaga kerja dan konsumsi yang dimasukkan dalam model bersifat separable, maka estimasi sistem persamaan produksi dan konsumsi dapat dilakukan secara terpisah, misalnya menganalisis sistem persamaan produksi dengan melakukan pendugaan melalui fungsi keuntungan atau fungsi biaya, sedangkan sistem persamaan konsumsi dengan menggunakan pendekatan Almost Ideal Demand System (AIDS) (De Janvry et al., 1996). Sedangkan, apabila sistem persamaan produksi dan konsumsi serta curahan tenaga kerja bersifat non-separable, maka teknik pendugaan yang lebih kompleks perlu dilakukan. Pendugaan antara lain dapat dilakukan dengan menggunakan Two Stage Least Square (2SLS) atau Three Stage Least Square (3SLS).

\section{METODE}

Penelitian ini dilaksanakan pada bulan September sampai dengan Oktober 2016 di Kecamatan Bangkinang, Kabupaten Kampar. Pengambilan sampel dengan cara metode accidential sampling. Sampel diambil berdasarkan petani yang kebetulan ada atau tersedia sesuai dengan konteks penelitian. Data yang diambil dalam penelitian ini adalah data primer. Data primer diperoleh melalui wawancara langsung kepada petani padi sawah dengan menggunakan kuisioner yang telah disusun.

Tahapan awal analisis data penelitian adalah spesifikasi model. Tahapan ini menggunakan pendekatan ekonometrik. Model yang dibangun adalah model persamaan simultan. Terdapat 17 persamaan yang dibangun dalam model, dimana 
terdiri dari 11 persamaan struktural dan 6 persamaan identitas. Pada aspek produksi, terdapat 1 persamaan struktural, Dilihat dari aspek curahan kerja terdapat 3 persamaan struktural (curahan kerja petani dalam usaha, penggunaan tenaga kerja luar keluarga, curahan kerja petani luar usaha) dan 2 persamaan identitas (total tenaga kerja dalam usaha dan total curahan kerja petani). Pada aspek pendapatan, terdapat 1 persamaan struktural yaitu pendapatan petani luar usaha, dan 3 persamaan identitas yaitu pendapatan petani dalam usaha, total biaya usaha dan pendapatan total petani. Aspek pengeluaran, terdiri dari 6 persamaan struktural (konsumsi pangan rumahtangga petani, konsumsi non pangan rumahtangga petani, investasi pendidikan rumahtangga petani, investasi usaha rumahtangga petani, pengeluaran rekreasi rumahtangga petani dan tabungan) dan 1 persamaan identitas yaitu konsumsi total rumahtangga petani.

Selanjutnya, Identifikasi model dilakukan untuk menduga parameter dari model persamaan simultan yang dibangun. Rumus identifikasi model berdasarkan order condition adalah sebagai berikut:

$$
(\mathrm{K}-\mathrm{M}) \geq(\mathrm{G}-1)
$$

Dimana $\mathrm{K}$ adalah Total peubah dalam model (peubah endogen dan peubah determinan), $\mathrm{M}$ adalah Jumlah peubah endogen dan eksogen yang dimasukkan ke dalam suatu persamaan tertentu dalam model, dan $G$ adalah Total persamaan (jumlah peubah endogen). Kriteria identifikasi model, Jika $(K-M)=(G-1)$, maka persamaan dalam model dinyatakan teridentifikasi secara tepat (exactly identified); Jika $(\mathrm{K}-\mathrm{M})<(\mathrm{G}-1)$, maka persamaan dalam model dinyatakan tidak teridentifikasi (unidentified); Jika (K-M) > (G-1), maka persamaan dalam model dinyatakan teridentifikasi (overidentified).

Hasil identifikasi menunjukkan bahwa setiap persamaan dalam model ekonomi rumahtangga petani padi sawah di Kecamatan bangkinang teridentifikasi berlebih (over identified). Model persamaan simultan yang setiap persamaannya teridentifikasi berlebih, maka pendugaan parameter dapat menggunakan metode Two Stage Least Square (2SLS). Uji F dan uji T digunakan untuk menguji seberapa berpengaruh nyata atau tidaknya peubah-peubah penjelas terhadap yang dipengaruhi (endogen). Dalam penelitian ini taraf nyata yang digunakan sampai 20 persen.

Perhitungan elastisitas digunakan untuk mendapatkan nilai respon dan persentase perubahan peubah yang dipengaruhi (endogen) terhadap yang mempengaruhinya (eksogen). Jika nilai elastisitas yang diperoleh besar dari 1 maka peubah yang dipengaruhi bersifat responsif terhadap perubahan peubah yang mempengaruhinya, sebaliknya, jika nilai elastisitas yang diperoleh lebih kecil dari 1 maka peubah yang dipengaruhi bersifat tidak responsif terhadap perubahan peubah yang mempengaruhinya. 2002):

Untuk menghitung nilai elastisitas dapat dirumuskan sebagai berikut (Sukirno,

$$
\mathrm{ESR} \quad=\frac{\partial Y}{\partial X}+\frac{\bar{X}}{\bar{Y}}=b \frac{\bar{X}}{\bar{Y}}
$$

dimana:

ESR = Elastisitas jangka pendek,

$\mathrm{B}=$ = Parameter dugaan dari peubah eksogen,

$\overline{\mathrm{X}} \quad=$ Rata-rata peubah eksogen, 
$\overline{\mathrm{Y}} \quad=$ Rata-rata peubah endogen (Mean Predicted hasil validasi model)

\section{HASIL DAN PEMBAHASAN}

Hasil dugaan model dalam setiap persamaan yang diperoleh cukup baik, terlihat dari nilai koefisien determinasi (R2) dari masing-masing persamaan berkisar antara 0,52530 sampai 0,96213 . Sementara itu nilai $F$ berkisar antara 11,07 sampai 347,18 , dan berbeda nyata dengan nol pada taraf 1 persen. Hal ini menunjukkan bahwa secara umum variabel-variabel bebas yang ada dalam persamaan mampu menjelaskan dengan baik variabel endogen.

Tabel 1. Hasil Dugaan Parameter dan Elastisitas

\begin{tabular}{|c|c|c|c|c|c|c|}
\hline & Persamaan & Notasi & $\begin{array}{l}\text { Parameter } \\
\text { Dugaan }\end{array}$ & t-hitung & $\operatorname{Pr}>|\mathbf{t}|$ & Elastisitas \\
\hline \multirow[t]{6}{*}{1} & Produksi & $Q$ & & & & \\
\hline & Intercept & - & -1853.69 & -4.82 & $<.0001$ & \\
\hline & $\begin{array}{l}\text { Luas Panen Padi } \\
\text { Sawah }\end{array}$ & LPPS & 1205.068 & 7.66 & $<.0001$ & 0,3044 \\
\hline & $\begin{array}{l}\text { Total Penggunaan } \\
\text { Tenaga Kerja Dalam } \\
\text { Usaha }\end{array}$ & TTKU & 23.94942 & 9.22 & $<.0001$ & 1,0063 \\
\hline & $\begin{array}{l}\text { Biaya Sarana } \\
\text { Produksi }\end{array}$ & BSP & 0.000022 & 1.12 & 0.2700 & \\
\hline & \multicolumn{6}{|c|}{$\mathrm{R}^{2}=0.96213 \mathrm{FV}$ alue $=347.18 \mathrm{Pr}>\mathrm{F}=<, 0001$ Durbin-Watson $=2.061118$} \\
\hline \multirow[t]{5}{*}{2} & $\begin{array}{l}\text { Curahan Kerja Dalam } \\
\text { Usaha }\end{array}$ & CKDU & & & & \\
\hline & Intercept & - & 141.5532 & 7.78 & $<.0001$ & \\
\hline & $\begin{array}{l}\text { Pendapatan Dalam } \\
\text { Usaha }\end{array}$ & PPD & $3.675 \mathrm{E}-6$ & 7.91 & $<.0001$ & 0,3182 \\
\hline & Usia Petani & UP & -0.33696 & -0.80 & 0.4269 & \\
\hline & \multicolumn{6}{|c|}{$\mathrm{R}^{2}=0.62262 \mathrm{FV}$ alue $=34.65 \mathrm{Pr}>\mathrm{F}=<.0001$ Durbin-Watson $=2.017771$} \\
\hline \multirow[t]{6}{*}{3} & $\begin{array}{l}\text { Tenaga Kerja Luar } \\
\text { Keluarga Petani }\end{array}$ & TKLP & & & & \\
\hline & Intercept & - & -3.33916 & -0.47 & 0.6430 & \\
\hline & $\begin{array}{l}\text { Pendapatan Dalam } \\
\text { Usaha }\end{array}$ & PPD & $1.533 \mathrm{E}-6$ & 7.54 & $<.0001$ & 1,2156 \\
\hline & Angkatan Kerja Petani & AKP & 1.143243 & 0.73 & 0.4676 & \\
\hline & Pendidikan Petani & EP & -0.39638 & -0.74 & 0.4614 & \\
\hline & \multicolumn{6}{|c|}{$\mathrm{R}^{2}=0.63494 \mathrm{FValue}=23.77 \mathrm{Pr}>\mathrm{F}=<, 0001$ Durbin-Watson $=2.126663$} \\
\hline \multirow[t]{5}{*}{4} & $\begin{array}{l}\text { Curahan Kerja Luar } \\
\text { Kerja }\end{array}$ & CKLU & & & & \\
\hline & Intercept & - & 269.4781 & 11.59 & $<.0001$ & \\
\hline & $\begin{array}{l}\text { Pendapatan Petani } \\
\text { Luar Usaha }\end{array}$ & PPLU & $5.253 E-7$ & 1.25 & 0.2194 & 0,0899 \\
\hline & $\begin{array}{l}\text { Curahan Kerja Dalam } \\
\text { Usaha }\end{array}$ & CKDU & -0.71829 & -9.21 & $<.0001$ & $-0,8480$ \\
\hline & \multicolumn{6}{|c|}{$\mathrm{R}^{2}=0.80631 \mathrm{FV}$ alue $=87.42 \mathrm{Pr}>\mathrm{F}=<, 0001$ Durbin-Watson $=1.611285$} \\
\hline 5 & \multicolumn{2}{|l|}{ TTKU=CKDU+TKLP } & \multicolumn{4}{|c|}{ TTKU=Total Curahan Kerja Dalam Usaha } \\
\hline 6 & \multicolumn{2}{|l|}{$\mathrm{TCKP}=\mathrm{CKDU}=\mathrm{CKLU}$} & \multicolumn{3}{|c|}{ TCKP=Total Curahan Kerja Petani } & \\
\hline \multirow[t]{2}{*}{7} & \multirow[t]{2}{*}{ PPD=RTR-TBU } & & \multicolumn{3}{|c|}{ RTR=Penerimaan Petani } & \\
\hline & & & \multicolumn{3}{|c|}{ TBU=Total Biaya Usahatani } & \\
\hline \multirow[t]{2}{*}{8} & \multirow[t]{2}{*}{$\mathrm{TBU}=\mathrm{UG}+\mathrm{BSP}$} & & \multicolumn{3}{|c|}{ UG=Upah Gaji } & \\
\hline & & & \multicolumn{3}{|c|}{ BSP=Biaya Sarana Produksi } & \\
\hline \multirow[t]{2}{*}{9} & $\begin{array}{l}\text { Pendapatan Petani } \\
\text { Luar Usaha }\end{array}$ & PPLU & & & & \\
\hline & Intercept & - & -7438532 & -0.72 & 0.4749 & \\
\hline
\end{tabular}




\begin{tabular}{|c|c|c|c|c|c|}
\hline Persamaan & Notasi & $\begin{array}{l}\text { Parameter } \\
\text { Dugaan }\end{array}$ & t-hitung & $\operatorname{Pr}>|t|$ & Elastisitas \\
\hline $\begin{array}{l}\text { Curahan Kerja Luar } \\
\text { Usaha }\end{array}$ & CKLU & 174000.3 & 5.36 & $<, 0001$ & 0,9776 \\
\hline Angkatan Kerja Petani & AKP & 3264388 & 3.70 & 0.0006 & 0,4397 \\
\hline Umur Petani & UP & -190560 & -1.62 & 0.1128 & $-0,3259$ \\
\hline Pendidikan Petani & $\mathrm{EP}$ & 509671.6 & 1.48 & 0.1464 & 0,1641 \\
\hline
\end{tabular}

$\mathrm{R}^{2}=0.54889 \mathrm{FValue}=12.17 \mathrm{Pr}>\mathrm{F}=<, 0001$ Durbin-Watson $=1.967306$

\begin{tabular}{lllll}
\hline 10 & PTP=PPD+PPLU PTP=Pendapatan Total Petani & & \\
\hline 11 & Konsumsi Pangan & KPP & & \\
\\
Petani
\end{tabular}

\begin{tabular}{|c|c|c|c|c|c|c|}
\hline \multirow[t]{7}{*}{12} & $\begin{array}{l}\text { Konsumsi Non } \\
\text { Pangan Petani }\end{array}$ & \multicolumn{5}{|l|}{ KNPP } \\
\hline & Intercept & - & -6427934 & -3.04 & 0.0042 & \\
\hline & $\begin{array}{l}\text { Pendapatan Total } \\
\text { Petani }\end{array}$ & PTP & 0.169679 & 2.90 & 0.0060 & 2,2796 \\
\hline & $\begin{array}{l}\text { Jumlah Anggota } \\
\text { rumahtangga Petani }\end{array}$ & JANP & 121134.0 & 0.58 & 0.5646 & \\
\hline & Investasi Pendidikan & IEP & -0.10327 & -1.23 & 0.2240 & \\
\hline & $\begin{array}{l}\text { Investasi Kesehatan } \\
\text { Rumahtangga Petani }\end{array}$ & KK & 1.819876 & 3.58 & 0.0009 & 0,1895 \\
\hline & \multicolumn{6}{|c|}{$R^{2}=0.52530$ FValue $=11.07 \mathrm{Pr}>\mathrm{F}=<, 0001$ Durbin-Watson $=2.192969$} \\
\hline 13 & \multicolumn{6}{|c|}{ KTP=KPP+KNPP KTP=Konsumsi Total Petani } \\
\hline \multirow[t]{6}{*}{14} & Investasi Pendidikan & IEP & & & & \\
\hline & Intercept & - & -9365742 & -2.32 & 0.0253 & \\
\hline & $\begin{array}{l}\text { Pendapatan Total } \\
\text { Petani }\end{array}$ & PTP & 0.365439 & 3.41 & 0.0015 & 2,5763 \\
\hline & Jumlah Anak Sekolah & JASP & 2828471 & 4.73 & $<, 0001$ & 0,8433 \\
\hline & $\begin{array}{l}\text { Konsumsi Pangan } \\
\text { Petani }\end{array}$ & KPP & -0.20644 & -1.13 & 0.2658 & $-0,8217$ \\
\hline & \multicolumn{6}{|c|}{$\mathrm{R}^{2}=0.69141 \mathrm{FV}$ alue $=30.62 \mathrm{Pr}>\mathrm{F}=<, 0001$ Durbin-Watson $=2.058668$} \\
\hline \multirow[t]{6}{*}{15} & Investasi Usaha & IUP & & & & \\
\hline & Intercept & - & 51699254 & 3.40 & 0.0015 & \\
\hline & $\begin{array}{l}\text { Pendapatan Total } \\
\text { Petani }\end{array}$ & PTP & 0.525640 & 1.16 & 0.2530 & \\
\hline & $\begin{array}{l}\text { Luas Panen Padi } \\
\text { Sawah }\end{array}$ & LPPS & 19864388 & 8.53 & $<.0001$ & 0,2420 \\
\hline & $\begin{array}{l}\text { Investasi Edukasi } \\
\text { Petani }\end{array}$ & IEP & -0.85522 & -1.45 & 0.1560 & $-0,0580$ \\
\hline & \multicolumn{6}{|c|}{$\mathrm{R}^{2}=0.72508 \mathrm{FV}$ alue $=36.04 \mathrm{Pr}>\mathrm{F}=<, 0001$ Durbin-Watson $=2.016755$} \\
\hline 16 & Pengeluaran Rekreasi & KRP & & & & \\
\hline
\end{tabular}




\begin{tabular}{|c|c|c|c|c|c|c|}
\hline & Persamaan & Notasi & $\begin{array}{l}\text { Parameter } \\
\text { Dugaan }\end{array}$ & t-hitung & $\operatorname{Pr}>|t|$ & Elastisitas \\
\hline & Intercept & - & -1880281 & $\overline{-} 1.78$ & 0.0822 & \\
\hline & $\begin{array}{l}\text { Pendapatan Total } \\
\text { Petani }\end{array}$ & PTP & 0.634471 & 5.54 & $<, 0001$ & \\
\hline & Konsumsi Total Petani & KTP & -0.62742 & -4.81 & $<.0001$ & $-0,0001$ \\
\hline & $\begin{array}{l}\text { Investasi Edukasi } \\
\text { Petani }\end{array}$ & IEP & -0.64777 & -5.73 & $<.0001$ & $-2,7103$ \\
\hline & Tabungan & TABP & -0.39841 & -2.17 & 0.0364 & $-0,4044$ \\
\hline & \multicolumn{6}{|c|}{$\mathrm{R}^{2}=0.83722 \mathrm{FV}$ alue $=51.43 \mathrm{Pr}>\mathrm{F}=<, 0001$ Durbin-Watson $=2.298603$} \\
\hline \multirow[t]{7}{*}{17} & Tabungan & TABP & & & & \\
\hline & Intercept & - & 3073586 & 2.17 & 0,0612 & \\
\hline & $\begin{array}{l}\text { Pendapatan Total } \\
\text { Petani }\end{array}$ & PTP & 0.603317 & 11.75 & $<, 0001$ & 4,2496 \\
\hline & Konsumsi Total Petani & KTP & -0.64591 & -11.82 & $<, 0001$ & $-2,9151$ \\
\hline & $\begin{array}{l}\text { Investasi Kesehatan } \\
\text { Rumahtangga Petani }\end{array}$ & KK & -0.99768 & -2.67 & 0.0108 & $-0,2356$ \\
\hline & Investasi Pendidikan & IEP & -0.58362 & -10.04 & $<, 0001$ & $-0,5990$ \\
\hline & \multicolumn{6}{|c|}{$\mathrm{R}^{2}=0.85963 \mathrm{FV}$ alue $=61.24 \mathrm{Pr}>\mathrm{F}=<, 0001$ Durbin-Watson $=2.364277$} \\
\hline
\end{tabular}

Hasil pendugaan parameter model ekonomi rumahtangga petani padi sawah di Kecamatan Bangkinang Kabupaten Kampar menunjukkan bahwa produksi dipengaruhi secara positif dan responsive oleh total tenaga kerja dalam usaha, meskipun tidak responsif tetapi luas panen padi sawah sangat berpengaruh terhadap produksi. Luas lahan petani yang minim menyebabkan produksi yang dihasilkan petani rendah. Hal ini disebabkan petani menanam hanya untuk mencukupi kebutuhan beras nya saja sehingga motivasi petani untuk mengembangkan kurang mengingat luas yang di miliki petani. Selain itu, 80 persen kepemilikan lahan petani masih berstatus milik orang lain dengan perhitungan bagi hasil. Jadi, perlu adanya kebijakan pemerintah terkait luas lahan.

Dari aspek alokasi waktu kerja dapat dinyatakan bahwa: pertama, curahan kerja dalam usaha dipengaruhi secara positif dan tidak responsif oleh pendapatan rumahtangga dalam usaha. Kedua, penggunaan tenaga kerja luar keluarga dipengaruhi secara positif dan responsif oleh pendapatan petani dalam usaha. Ketiga, curahan kerja luar usaha dipengaruhi secara positif dan tidak responsif oleh pendapatan rumahtangga petani di luar usaha namun, dipengaruhi secara negatif dan tidak responsif oleh curahan kerja rumahtangga petani dalam usaha. Dapat dinyatakan bahwa faktor utama yang penentu keputusan rumahtangga untuk mencurahkan waktu kerja adalah besarnya pendapatan yang diterimanya.

Dilihat dari aspek pendapatan, peubah curahan kerja rumahtangga di luar usahatani padi dan peubah angkatan kerja petani padi sawah berpengaruh positif terhadap pendapatan rumahtangga petani padi sawah diluar usaha. Dari aspek pengeluaran dapat dinyatakan bahwa: pertama, konsumsi pangan dipengaruhi secara positif tetapi tidak responsif oleh pendapatan total petani, jumlah anggota keluarga petani dan investasi edukasi petani. Kedua, konsumsi non pangan dipengaruhi secara positif dan responsif oleh pendapatan total rumahtangga petani dan pengeluaran kesehatan yang tidak responsif. Ketiga, investasi edukasi petani dipengaruhi secara positif oleh pendapatan total rumahtangga petani dan jumlah anak sekolah namun hanya responsif terhadap perubahan pendapatan total 
rumahtangga petani sedangkan konsumsi pangan mempengaruhi investasi edukasi petani secara negatif tetapi tidak responsif. Keempat, investasi usaha dipengaruhi secara positif tetapi tidak responsif oleh luas panen padi sawah namun dipengaruhi secara negatif tetapi tidak responsif oleh investasi edukasi petani. Kelima, pengeluaran rekreasi dipengaruhi secara negatif dan responsif oleh investasi edukasi petani. Keenam, tabungan dipengaruhi secara positif dan responsif oleh pendapatan total rumahtangga petani namun dipengaruhi secara negatif tetapi tidak responsif oleh konsumsi total rumahtangga petani, Investasi Kesehatan Rumahtangga Petani Padi Sawah dan investasi pendidikan.

\section{KESIMPULAN}

Hasil penelitian menunjukkan bahwa faktor-faktor yang mempengaruhi keputusan ekonomi rumahtangga adalah faktor internal. Peubah total tenaga kerja dalam usaha responsif mempengaruhi produksi. Alokasi waktu kerja dipengaruhi secara responsif oleh pendapatan dalam usahatani padi sawah. Sementara itu, tidak ada peubah yang responsif mempengaruhi pendapatan luar usahatani padi sawah. Pengeluaran rumahatangga dipengaruhi secara responsif oleh pendapatan total rumahtangga, tabungan, total curahan kerja rumahtangga, dan konsumsi total rumahtangga.

\section{DAFTAR PUSTAKA}

Becker, G.S. 1965. A Theory of The Allocation of Time. The Economic Journal 75(299): 493-517. https://doi.org/10.2307/2228949

Becker, G.S. 1976. The Economic Approach to Human Behaviour. London: The University of Chicago Press. https://doi.org/10.7208/chicago/9780226217062.001.0001

De Janvry, Alain, M. Fafchamps, and E. Sadoulet. 1991. Peasant Household Behaviour with Missing Markets: Some Paradoxes Explained. The Economic Journal 101(409): 1400-1417. https://doi.org/10.2307/2234892

Grossbard, S.A. 2010. Independent Individual Decision-Makers in Household Models and the New Home Economics. IZA Discussion Paper 5138: 1-15. https://ssrn.com/abstract $=1663178$

Hernanto, F. 1996. IImu Usahatani. Jakarta: Penebar Swadaya.

Singh, I., L. Squre, and J. Strasuss. 1986. A Survey of Agricultural Household Models: Recent Findings and Policy Implication. The World Bank Economic Review 1(1): 149-179. https://doi.org/10.1093/wber/1.1.149

Sukirno, S. 2002. Pengantar Teori Mikroekonomi. Jakarta: Raja Grafindo Persada. 